\title{
DRŽAVA, MATI ALI MAČEHA IZOBRAŽEVANJU ODRASLIH*
}

\section{Izhodišča in podlage za pogovor z ministrom}

\section{SPODBUDNI ZNANILCI RAZVOJA V PRVEM OBDOBJU SAMOSTOJNE SLOVENIJE}

Ob osamosvojitvi Slovenije in nastanku nove države se je tudi v razmerju do izobraževanja odraslih oblikovala razmeroma obetavna politika, ki se je kazala v vrsti ukrepov Vlade Republike Slovenije za razvoj izobraževanja odraslih. To so bili zlasti posebna sredstva $\mathrm{v}$ proračunu Republike Slovenije za izobraževanje odraslih, ustanovitev posebnega sektorja za izobraževanje odraslih pri Ministrstvu za šolstvo in šport in ustanovitev Andragoškega centra Slovenije kot posebne institucije za pospeševanje razvoja izobraževanja odraslih v Sloveniji. Pripravljati se je začela nova zakonodaja za vzgojo in izobraževanje, tudi za izobraževanje odraslih, in sprejet je bil poseben program študija andragogike na Filozofski fakulteti v Ljubljani.

\section{OBDOBJE INTENZIVNEGA RAZVOJNEGA ZAGONA}

Sprejeta politika in intenzivno delo, zlasti $\mathrm{v}$ Andragoškem centru Slovenije, sta v prvi polovici 90 . let spodbudila številne aktivnosti, ki označujejo to obdobje kot čas intenzivnega razvojnega zagona. Začelo se je temeljito raziskovanje sistema izobraževanja odraslih v Sloveniji, ki se je končalo leta 1995 in določilo temeljne prvine za koncipiranje sistema in razvoja izobraževanja odraslih v Sloveniji.

Na podlagi Bele knjige so bili leta 1996 sprejeti novi zakoni za vzgojo in izobraževanje, med njimi tudi zakon o organizaciji in finan- ciranju vzgoje in izobraževanja (ZOFI) ter zakon o izobraževanju odraslih (ZIO), ki so med drugim za izobraževanje odraslih določili omogočanje vzgoje in izobraževanja, ki ustrezata stopnji razvoja in posameznikovi življenjski dobi; spodbujanje vseživljenjskosti izobraževanja; dostopnost izobraževanja pod enakimi pogoji in pripravo nacionalnega programa izobraževanja odraslih (Strokovni svet za izobraževanje odraslih je leta 1998 sprejel strokovne podlage).

Konec februarja je Andragoško društvo Slovenije organiziralo javni pogover $z$ ministrom za šolstvo in šport, da bi spodbudili razvoj izobraževanja odraslih $v$ Sloveniji. Na pogevor so bili poleg ministra dr. Pavleta Zgage povabljeni še državni sekretar za srednje šole in izobraževanje odraslih Alojz Pluško, državni sekretar za visoko šolstvo dr. Zdenko Medveš, vedja sektorja za izobraževanje odraslih mag. Jože Miklave, predstavniki izobraževalnih podjetij, ljudskih univerz ter institucij, ki so povezane $z$ izobraževanjem. »Pogovor razumemo kot spodbudo za sistemsko reŠevanje izobraževanja $v$ celoti, tako tudi izobraževanja odraslih, in kot eno $v$ vrsti nadajjnjih razprav, ki bodo omogočile sprejem Nacionalnega programa izobraževanja odraslih, $«$ je v svojem nastopu poudaril minister dr. Pavle Zgaga. V nadaljevanju je obljubil rednejša srečanja ministrstva za šolstvo $\mathrm{z}$ izobraževalci odraslih in že kar napovedal majski posvet v Portorožu, katerega tema bo kakovost v izobraževanju odraslih. Obljubil je tudi širitev sektorja za izobraževanje odraslih $\mathrm{v}$ letošnjem letu, glede sprejema Nacionalnega programa izobraževanja odraslih pa je dejal, da bo prišel v parlamentarno proceduro spomladi. Dodal je tudi, da ni možnosti, da bi bil sprejet še $\mathrm{v}$ tem mandatu državnega zbora.

Objavljamo izhodišča za razpravo, ki jih je pripravil dr. Zoran Jelenc, član društva in ustanovitelj ter nekdanji direktor Andragoškega centra Slovenije, in vas vabimo k nadaljnji razpravi. 
V Beli knjigi o vzgoji in izobraževanju v Republiki Sloveniji (MŠŚ, Ljubljana, 1995) je bilo objavljeno poglavje Razvoj izobraževanja odraslih, ki med drugimi opredelitvami določa tudi zelo obetavna in napredna načela o razvoju izobraževanja odraslih, to so: izobraževanje in učenje odraslih kot sestavina strategije in koncepta vseživ ljenjskega izobraževanja; enakovredno in celostno upoštevanje vseh potreb; sistemska povezanost ponudbe; raznovrstnost, fleksibilnost izobraževalnih možnosti; povezanost in enakopravnost izobraževanja ter učenja; partnerstvo pri upravljanju in financiranju; inovativnost $z$ upoštevanjem pozitivne tradicije; mednarodna primerljivost; razvojna strategija: temeljitost, a postopnost uresničevanja zasnove.

Številni razvojni projekti so spodbudili razvoj novih možnosti učenja in izobraževanja v Sloveniji (zlasti učenje za življenjsko uspešnost, študijski krožki, središča za samostojno učenje, borza znanja, projektno učenje za mlade, izobraževanje brezposelnih, nove možnosti ugotavljanja in potrjevanja znanja, informacijsko-svetovalno delo, izobraževanje na daljavo itn.), izobraževanje odraslih pa je bilo včlenjeno $\mathrm{v}$ projekt Prenova izobraževanja odraslih v Sloveniji.

\section{OBDOBJE INTENZIVNIH MEDNARODNIH POBUD IN PROJEKTOV}

V skladu z usmeritvami v svetu pod skupnim geslom »Vseživljenjsko učenje za vse« (Lifelong Learning for All), zlasti OECD (ministrska konferenca 1996), Unesca (strategija za srednjeročno obdobje, 1995; peta mednarodna konferenca o izobraževanju odraslih, 1997), se postopno spreminjajo nacionalne politike razvoja in sistemske ureditve vsega izobraževanja, tako da se začetno izobraževanje (to je izobraževanje otrok in mladine) ter nadaljevalno izobraževanje (to je izobraževanje odraslih) povezujeta $\mathrm{v}$ celovit sistem vseživljenjskega učenja (VŽU) in temu ustrezno strategijo VŽU. V Hamburški deklaraciji o učenju odraslih, ki so jo sprejeli udeleženci pete Unescove mednarodne konference o izobraževanju odraslih, je skupno priporočilo, da države udele- ženke oblikujejo svoje strategije razvoja VŽU, poleg tega pa še vrsto priporočil, kako naj to izpeljejo. Sklepi, sprejeti na konferenci, zavezujejo tudi Slovenijo, ki jo je na konferenci zastopala uradna državna delegacija pod vodstvom tedanjega državnega sekretarja in zdajšnjega ministra dr. Pavleta Zgage.

V Sloveniji smo na sprejetje takšne strategije, vsaj kar zadeva izobraževanje odraslih, temeljito strokovno pripravljeni. V Andragoškem centru Slovenije so poleg že prej navedenih strokovnih gradiv (Bela knjiga, strokovne podlage za Nacionalni program izobraževanja odraslih) pripravili sintezno gradivo Koncepcija, strategija in razvoj za razvoj izobraževanja odraslih v Sloveniji (nosilec dr. Zoran Jelenc), v katerem so aktualizirali dozdajšnje sistemske opredelitve o izobraževanju odraslih v Sloveniji z novejšimi pobudami in dosežki na tem področju v svetu. Mednarodne pobude uresničujemo, kolikor je mogoče, tudi v praksi. Tako smo med prvimi v svetu izpeljali kot nacionalni projekt Teden vseživljenjskega učenja, ki bo letos potekal že petič.

\section{ZNAMENJA NOVE KRIZE IN STAGNACIJE}

Kljub navedenim uspehom in dokazom, kako smo strokovno pripravljeni in kako bi lahko $\mathrm{v}$ izobraževanju odraslih postopno dosegli tudi najrazvitejše, se v zadnjih letih kažejo znamenja stagnacije in nekonsistentnega vodenja državne politike do razvoja izobraževanja odraslih. To je mogoče videti tudi iz ugotovitev o zdajšnjem stanju:

- načela o vseživljenjskosti izobraževanja kot temelja za razvoj izobraževanja odraslih nimajo ustrezne potrditve $\mathrm{v}$ ukrepih nacionalne politike o vzgoji in izobraževanju: ni zagotovljena celovitost strategije vseživljenjskosti učenja, ki jo sestavljata dve enako pomembni in enakopravni področji, to sta začetno in nadaljevalno izobraževanje, ki se komplementarno povezujeta; 
- sistemsko urejanje izobraževanja odraslih zaostaja za urejanjem izobraževanja otrok in mladine, znamenja za to pa so zlasti:

- izobraževanje odraslih je izrazito zapostavljeno pri upravljanju: nima posebnega sekretarja v MŠŠ, ki bi vodil področje izobraževanja odraslih (ali tudi izpeljevo celovite strategije vseživljenjskosti učenja); sektor za izobraževanje odraslih je najšibkejši sektor MŠŠ; med drugimi sektorji MŠŠ in sektorjem za izobraževanje odraslih ni dovolj sodelovanja; na ravni lokalne uprave ni niti ustreznih upravnih niti predstavniških enot, ki bi ustrezno skrbele za razvoj izobraževanja odraslih v lokalnih skupnostih;

- zakonodaja, ki ureja bodisi celotno organizacijo in financiranje izobraževanja odraslih (ZOFI) bodisi posamezna področja, na katerih deluje (zlasti izobraževanje na posameznih stopnjah šolskega sistema in nadaljnje izobraževanje za potrebe dela), ureja izobraževanje odraslih $\mathrm{v}$ primerjavi $\mathrm{z}$ izobraževanjem otrok in mladine le minimalno in mu ne zagotavlja sistemske enakovrednosti; priprava podzakonskih predpisov (dokumentacija za področje izobraževanja odraslih, standardi itn.) na področju izobraževanja odraslih se pripravlja prepočasi ali pa sploh ne;

- omrežje izvajalcev in programov ne zagotavlja zakonsko določene »dostopnosti izobraževanja pod enakimi pogoji (2. člen ZIO) in »omogočanja vzgoje in izobraževanja, ki ustreza stopnji razvoja in življenjski dobi posameznika« (2. člen ZOFI); ima številne slabosti in pomanjkljivosti, med drugim tudi te, da je po Sloveniji neenakomerno razpršeno in kakovostno neizenačeno; na področju izobraževanja odraslih je bilo zaradi zakonskih (nedomišljenih) sprememb odpravljenih približno 100 programov, nadomestila pa ni;

- financiranje izobraževanja odraslih je med vsemi področji izobraževanja sistemsko najmanj urejeno, poleg tega pa ne zagotavlja za- dovoljevanja celo tistih potreb, ki so zakonsko (Nacionalni program) opredeljene kot nacionalni interes; sprejemanje Nacionalnega programa je po sprejetju strokovnih podlag zastalo; delež, ki ga država namenja za izobraževanje odraslih po letu 1996 upada (čeprav sredstva sicer nominalno rastejo); 1okalne skupnosti imajo le minimalne zakonske obveznosti, vloga socialnih partnerjev pri zagotavljanju virov (finančnih, kadrovskih, prostorskih) pa ni sistemsko opredeljena;

- razvojna in raziskovalna infrastruktura za izobraževanje odraslih je izrazito pomanjkljiva in nezadostna, saj poleg ACS ni drugih specializiranih razvojnih središč z ustrezno zmogljivostjo, ki bi bila potrebna za zadovoljevanje naraščajočih potreb na področjih, kot so poklicno izobraževanje, osnovno in srednje izobraževanje, visokošolsko izobraževanje, izobraževanje $v$ delovnih organizacijah in za potrebe dela ter zaposlitve, izobraževanje starejših, izobraževanje za demokracijo itn.; tudi ACS čedalje bolj postaja le svetovalno-razvojna služba za potrebe ministrstev in izgublja vlogo avtonomne razvojno-raziskovalne ustanove za izobraževanje odraslih, kakršno je imel v začetku svojega delovanja; informacijska baza za ugotavljanje in spremljanje dejavnosti izobraževanja odraslih (statistika, informacijski sistem MŠŠ itd.) je pomanjkljiva ali pa je sploh ni;

- izobraževanje andragogov, tudi tisto, ki ga zahtevajo zakonski predpisi, ni organizirano tako, da bi vsi kandidati lahko sprotno pridobivali zahtevano izobrazbo; poleg tega pa so programi za pridobitev "pedagoško-andragoške« izobrazbe za andragoge neustrezni;

- različni sistemski ukrepi, kot je davčna politika, ne upoštevajo izobraževanja odraslih kot dejavnika spodbujanja rasti in razvoja.

\section{dr. Zoran Jelenc}

* Prispevek je bil objavljen v Novičkah, zaradi pomembnosti pa ga objavljamo tudi v naši reviji. 